\title{
Urban Infrastructure and Water Management-Science Capabilities of the U.S. Geological Survey
}

Managing the urban-water cycle has increasingly become a challenge for water-resources planners and regulators faced with the problem of providing clean drinking water to urban residents. Sanitary and combined sanitary and storm sewer networks convey wastewater to centralized treatment plants. Impervious surfaces, which include roads, parking lots, and buildings, increase stormwater runoff and the efficiency by which runoff is conveyed to nearby stream channels; therefore, impervious surfaces increase the risk of urban flooding and alteration of natural ecosystems. These challenges will increase with the expansion of urban centers and the probable effects of climate change on precipitation patterns. Understanding the urban-water cycle is critical to effectively manage water resources and to protect people, infrastructure, and urban-stream ecosystems. As a leader in water-supply, wastewater, and stormwater assessments, the U.S. Geological Survey (USGS) has the expertise and resources needed to monitor, model, and interpret data related to the urban-water cycle and thereby enable water-resources managers to make informed decisions.

\section{Expertise and Resources}

The USGS scientists of the Northeast Region Urban Landscapes Capability Team share expertise and resources to provide and interpret data on a wide range of urban-related issues at local, regional, and national levels. The USGS has been studying the effects of urbanization on natural resources - groundwater and surface-water quality, ecosystems, and geologic resources - throughout the United States for more than a century. Continuous water-quality monitoring is used to assess trends in water quality and to detect potential problems before an entire water-supply system is impacted. Groundwater monitoring and modeling are used in a variety of aquifer settings to assess the effects of groundwater pumping for public supply and infrastructure dewatering (for example, pumping groundwater to prevent flooding of subways). Scientists with the USGS evaluate groundwater and surface-water responses to changes in water management. Advanced geophysical equipment is used to understand the effects of compromised underground water-supply infrastructure (such as aqueducts), to understand the potential for geothermal development, and to understand the capacity for artificial storage and recovery of gray water. Advanced geophysical equipment also is used to guide the development of watersupply and wastewater conveyance systems in heavily developed areas. The expertise of USGS scientists also is applied when water quality and quantity is monitored to assess the effectiveness of various stormwater control measures (SCMs), including green infrastructure.

\section{Water Supply Infrastructure}

Monitoring water quality and quantity are critical for maintaining safe and reliable drinking water supplies. Contaminants (such

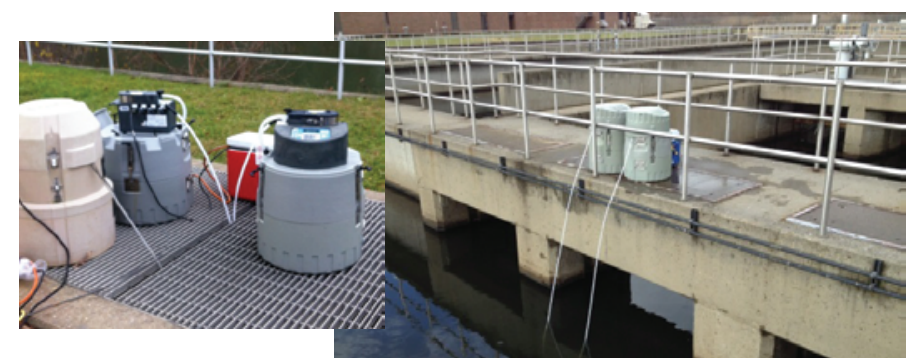

Automated influent and effluent sampling at a wastewater treatment plant as part of a regional assessment of water quality. Photographs by Tia-Marie Scott, U.S. Geological Survey. as sediment, nutrients, metals, and chloride) can compromise water supplies and require expensive treatment systems. Scientists with the USGS frequently work with water purveyors and municipalities to develop strategies for evaluating the water-supply system, including not only the quality of water but also the infrastructure by which water is retained and transported.

\section{Wastewater Treatment Infrastructure}

Without proper treatment, contaminants (such as nutrients, organic and inorganics compounds, pharmaceuticals and personal care products, and pathogen) may be discharged to receiving waters causing poor water quality, mutations to aquatic organisms, and beach advisories or closures. The effects of damaged or underperforming wastewater treatment plants, combined sewer overflows, and leaking and misconnected infrastructure can be difficult to determine without a properly devised monitoring program. Through influent/effluent monitoring and contaminant-source tracking, the USGS provides the near real-time data necessary for urban watershed assessments to aid water-resources managers in determining the effectiveness of wastewater treatment and in their work with sewer authorities to identify infrastructure problems.

\section{Stormwater Infrastructure}

Traditional engineering methods, grey infrastructure, are designed to rapidly convey storm runoff from developed areas to nearby stream channels or estuary. Green infrastructure is designed to reduce stormwater runoff through nontraditional control measures such as rain gardens and bioswales. Both types of infrastructure help protect cities from flood-related property damage and in some cases, decrease the contaminant loads in storm runoff. Green infrastructure is designed to help restore the natural water cycle by enhancing stormwater infiltration and evapotranspiration. Understanding whether the stormwater infrastructure is contributing to or mitigating the adverse effects of urbanization on nearby waterways is important. The USGS combines proven field methods with state-ofthe-art technology to assess the effectiveness of SCMs at multiple scales. Whether monitoring the volumetric and contaminant mass balance of a single rain garden at the plot scale or the cumulative effect of several SCMs dispersed throughout an urban catchment, the USGS can provide the data necessary to help water-resources managers make informed decisions to achieve compliance with local and State contaminant reduction goals. 
The USGS makes use of hydrologic and contaminant loading models so that information learned from grey and green infrastructure field measurements can be extrapolated into the surrounding urban landscape as a way to simulate the spatial and temporal influence of SCMs on stormwater quantity and quality compared to some baseline condition. For example, a calibrated contaminant loading model is being used to predict the potential benefit of street cleaning on sediment loads from stormwater runoff to nearby waterways.

\section{Examples of USGS Urban Infrastructure Studies}

\section{Regional Climate Variability and Patterns of Urban Development}

Effects on the urban water cycle and nutrient export.-USGS scientists have established and maintained discharge stations at several urban watersheds in Maryland. http://md.water.usgs.gov/ projects/sw/water-sustainability.html

\section{Determination of the Natural Resiliency of Critical Infrastructure in Response to Flooding Events}

This project seeks to identify where key investments in green infrastructure may increase resiliency to intensified coastal storms, rising relative sea levels, and flooding in the Baltimore, Md., region. http://md.water.usgs.gov/projects/sw/green-infrastructure.html

\section{Rockland County Water-Resource Assessment}

USGS scientists have assessed public water supply sources for viability and sustainability in Rockland County, New York. Surface-water impoundments, fractured bedrock, and glacial aquifers were monitored, along with sewer outfalls, to determine
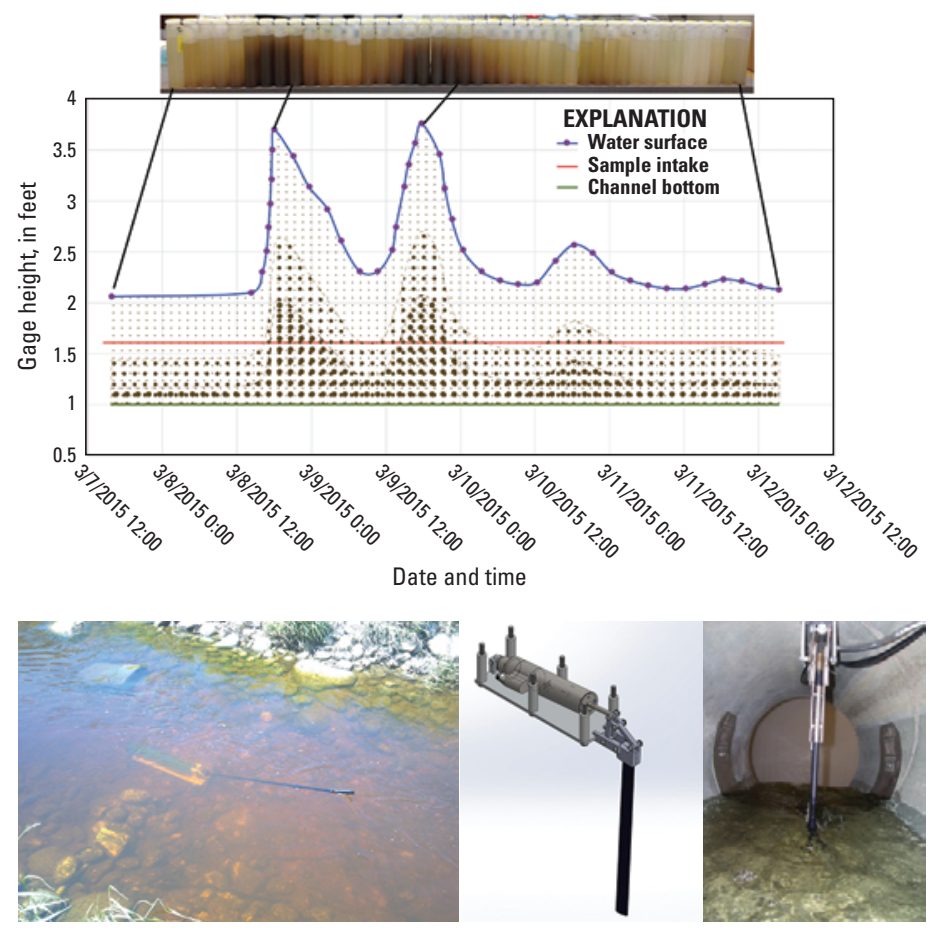

The Depth Integrated Sample Arm (DISA; above center) is an example of a state-of-the art technology that the U.S. Geological Survey is developing to obtain a true representation of sediment concentration and loads. The technology is especially useful in flashy systems where sediment concentrations vary substantially with water flow and depth such as stormwater and sewer tunnels (above right) or ephemeral streams (above left). The DISA solves the problem of collecting too much stratified sediment when using a fixed-point sample intake as seen in the above hydrograph and sample collection jars (https://pubs.er.usgs.gov/publication/70133842). Photographs by William Selbig, U.S. Geological Survey. differences in supply versus treatment relative to potential use. http://ny.water.usgs.gov/projects/rockland/index.html

\section{Effectiveness of Three Best Management Practices for Highway- Runoff Quality Along the Southeast Expressway, Boston, Mass.}

The USGS has studied the effectiveness of three best management practices in reducing suspended-sediment loads and related constituents along the Southeast Expressway in Boston, Mass. http://pubs.er.usgs.gov/publication/wri024059

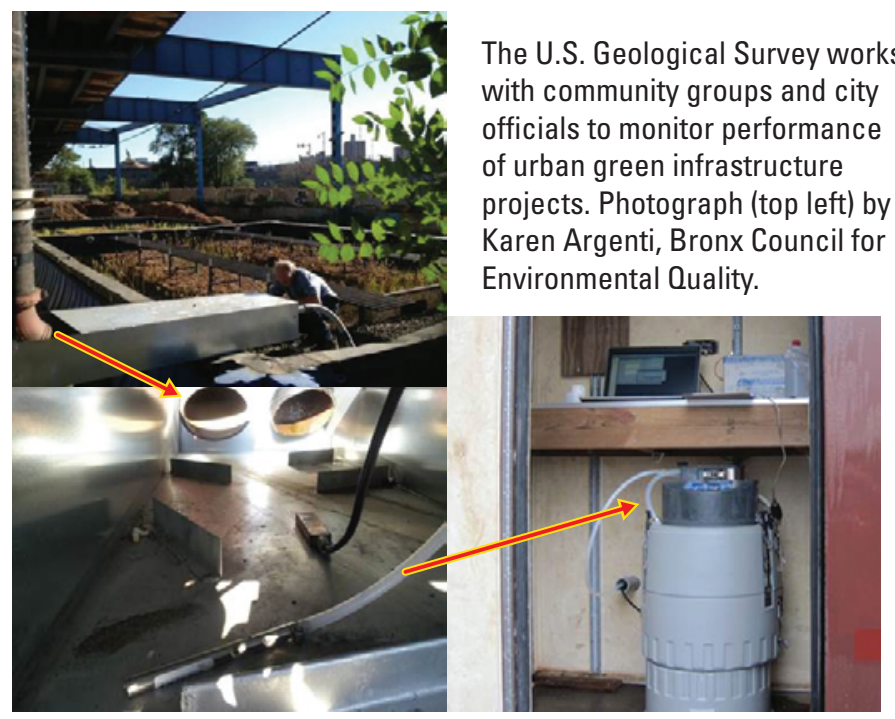

\section{Partnering Opportunities}

As the Nation's largest hydrologic, geologic, and biologic science and mapping agency, the USGS provides scientific understanding about natural resource conditions, issues, and problems. The diverse scientific expertise of USGS scientists enables the USGS to carry out site-scale or large multiscale, multidisciplinary investigations and provide impartial scientific information to resource managers, planners, and other customers. The Northeast Region Urban Landscapes Capability Team is committed to expanding urban infrastructure studies needed to manage the water resources of the United States, including the infrastructure used to convey potable water, wastewater, and stormwater. The USGS has a long history of collaborative science with diverse partners including local, State, Federal, and Tribal agencies; nonprofit organizations; academic institutions; watershed groups; and other water resources entities. Opportunities for jointly funded programs are available through the Cooperative Water Program (http://water.usgs.gov/coop/).

\section{References Cited}

Selbig, W.R., 2015, Characterizing the distribution of particles in urban stormwater-advancements through improved sampling technology: Urban Waters Journal, v. 12, issue 2, p. 111-119, accessed April 12, 2016, at https://pubs.er.usgs.gov/publication/70133842.

Smith, K.P., 2002, Effectiveness of three best management practices for highway-runoff quality along the Southeast Expressway, Boston, Massachusetts: U.S. Geological Survey Water-Resources Investigations Report 2002-4059, 62 p. [Also available at http://pubs.er.usgs.gov/publication/wri024059.]

By Shawn C. Fisher, Rosemary M. Fanelli, and William R. Selbig

\section{For more information about these USGS projects and about partnering opportunities, contact:}

USGS Northeast Region Urban Landscapes Capability Team

Email: GS-NE_ULCT@usgs.gov

or contact your local USGS office

https://www.usgs.gov/contact_us 